\title{
Müşteri Memnuniyetinin Öncülleri ve Ardılları: Otel İşletmeleri Üzerine Bir Model Analizi
}

\author{
Antecedents and Consequences of Customer Satisfaction: A Model Analysis on Hotel Enterprises
}

\author{
Serhat Adem SOP* \\ *Dr. Öğr. Üyesi, Burdur Mehmet Akif Ersoy Üniversitesi Turizm İşletmeciliği ve Otelcilik Yüksekokulu, 15030, Burdur. \\ E-posta: serhatademsop@gmail.com \\ ORCID NO: 0000-0001-9096-9496
}

MAKALE BILGILERI

Makale işlem bilgileri:

Gönderilme tarihi: 31 Aralık 2018

Düzeltme: 10 Şubat 2019

Kabul: 20 Şubat 2019

Anahtar sözcükler: Fonksiyonel uyum, Benlik uyumu, Müşteri memnuniyeti, Müşteri sadakati, Otel işletmeleri.

\section{ARTICLE INFO}

\section{Article history:}

Submitted: 31 December 2018

Resubmitted: 10 February 2019

Accepted: 20 February 2019

Key words: Functional congruity, Self-congruity, Customer satisfaction, Customer loyalty, Hotels.

\section{Öz}

Bu araştırmada, müşteri memnuniyetinin öncülleri olarak fonksiyonel uyum ve benlik uyumu, ardılları olarak ise tutumsal sadakatin bilișsel, duygusal ve eğilimsel sadakat bileșenleri ele alınmıștır. Araștırmanın amacı, fonksiyonel uyumun ve benlik uyumunun müșteri memnuniyetine etkilerini belirlemek ve müșteri sadakatinin oluşumunda memnuniyetin rolünü açıklamaktır. Araştırmanın veri toplama aracı Fethiye destinasyonundaki beş yıldızı otel işletmelerinde konaklayan 309 katılımcıya uygulanmış, araştırmanın kuramsal modeli ise PLSSEM yoluyla analiz edilmiștir. Bu bağlamda, fonksiyonel uyumun ve benlik uyumunun müșteri memnuniyetini olumlu etkilediği, ancak fonksiyonel uyumun etkisinin daha yüksek olduğu tespit edilmiştir. Ayrıca, müşteri memnuniyetinin bilişsel ve duygusal sadakati olumlu etkilediği, ancak eğilimsel sadakat üzerinde anlamlı bir etkisinin bulunmadığı sonucuna ulaşıımıştır.

\section{ABSTRACT}

In this research, functional congruity and self-congruity are considered as the antecedents, and cognitive, affective and conative components of customer loyalty are discussed as the consequences of customer satisfaction. The purpose of this research is to determine the effects of functional congruity and self-congruity on customer satisfaction and to explain the role of satisfaction in building customer loyalty. Data collection tool of the research was applied to $\mathbf{3 0 9}$ participants staying in five-star hotels in Fethiye destination and the theoretical model was tested through PLS-SEM analysis. Within this context, it was determined that functional congruity and self-congruity positively influence customer satisfaction, but the effect of functional congruity is greater. It was also concluded that customer satisfaction positively influences cognitive and affective loyalty, but its effect on conative loyalty is not significant.

\section{GiRiş}

Müşteri odaklı pazarlama yaklaşımını benimseyen turizm işletmeleri, hedef tüketicilerin ve müşterilerin gereksinim ve isteklerini belirleyerek müşteri memnuniyetini sağlamaya çalışmaktadır (Chon ve Olsen 1991). Sektörün bu yaklaşımına paralel olarak turizm alanındaki bilimsel araştırmalarda da müşteri memnuniyeti konusu sıkça ele alınmakta ve memnuniyeti etkileyen öncüllerin ve memnuniyetin çıktısı olan ardılların anlaşılması hedeflenmektedir. Bu bağlamda yürütülen bir meta-analiz çalışmasında memnuni- yetin öncülleri olarak kalite, imaj, çevre ve alg1lanan değer, ardılları olarak ise satın alma eğilimi, ağızdan ağza duyurum, güven ve sadakatin öne çıktığı vurgulanmaktadır (Ladeira vd. 2016). Ancak, müşteri memnuniyetinin daha kapsam11 bir çerçeveden yorumlanabilmesi için müşteri memnuniyetiyle ilişkilendirilen bu araştırma değişkenlerinin genişletilmesi gerekmektedir. Bu amaçla yapılan bazı araştırmalarda imaj uyumu teorisinin müşteri memnuniyetiyle ilişkilendirildiği görülmektedir (Back 2005; Ekinci vd. 2008; Sreejesh vd. 2015). Örneğin Sreejesh vd. (2015), 
otel müşterilerinin fonksiyonel uyum (bireyin otele yönelik fonksiyonel beklentileri ile otelin performans çıktısı arasındaki uyum) ve benlik uyumu (bireyin benlik algisı ile otelin sembolik imajı arasındaki uyum) değerlendirmelerinin otel işletmesine yönelik memnuniyet düzeyini arttırdığını savunmaktadır. Bazı araştırmalarda ise müşteri memnuniyetinin ardıllarının yeniden yorumlandığı anlaşılmaktadır. Örneğin Yuksel vd. (2010), memnuniyetin temel çıktısı konumunda görülen müşteri sadakatinin bilişsel, duygusal ve eğilimsel bileşenlerini ele alarak, memnuniyetin müşteri sadakati üzerine etkilerini kapsamlı bir model üzerinden tartışmaktadır.

Mevcut araştırmada imaj uyumunun bileşenleri (fonksiyonel uyum ve benlik uyumu) müşteri memnuniyetinin öncülleri olarak ele alınmış, memnuniyetin ardılları ise Oliver'ın (1999) çok boyutlu sadakat modelinden hareketle bilişsel, duygusal ve eğilimsel sadakat olarak yorumlanmıştır. Dolayısıyla araştırmanın amacı, fonksiyonel uyum ve benlik uyumunun müşteri memnuniyetine etkilerini belirlemek ve memnuniyetin müşteri sadakatinin oluşumundaki rolünü açıklamaktır. Alanyazında imaj uyumu ve sadakat bileşenlerinin müşteri memnuniyetiyle ilişkisini tek bir model üzerinden inceleyen başka bir çalışmaya rastlanamaması, araştırmanın önemini ve alanyazına olan özgün katkısını göstermektedir. Bu bağlamda mevcut araştırma, müşteri memnuniyetini analiz etme ve tüketici davranış1nı yorumlama açısından otel yöneticilerine de bir bakış açısı sunmaktadır.

\section{KURAMSAL ÇERÇEVE}

\section{Müşteri Memnuniyeti}

Müşteri memnuniyeti kavramı, tüketim sürecinde müşterinin gereksinim ya da beklentilerinin karşılanmasıyla oluşan olumlu duyguyu/ tepkiyi ifade etmek üzere kullanılmaktadır (Oliver 1999). Bu kapsamda müşteri memnuniyeti, satın alınan mal veya hizmetin sağladı $\breve{g} 1$ yarar ile müşterinin beklenti ve isteklerinin uyuşması durumunda meydana gelmektedir (Kılıç ve Pelit 2004). Bu olgunun pazarlama teorisi bağlamında ilk kez R. N. Cardozo tarafından 1965 yılında ele alındığı, A. Pizam, Y. Neumann ve A. Reichel'ın ise 1978 yılındaki çalışmalarıyla müşteri memnuniyetini ilk kez turizm ve konaklama sektörü açısından yorumladıkları ileri sürülmektedir (Ladeira vd. 2016). Zamanla gerek pazarlama gerekse turizm disiplini içerisinde önemli bir araştırma konusu haline gelen müşteri memnuniyeti (Chi ve Qu 2008), işletmelerin rekabet gücünü koruyabilmesine ve gelirlerini arttırmasına olanak sağladığı için otel işletmeleri açısından da önem arz etmektedir (Su 2004). Zira müşteri memnuniyeti, müşterinin işletmeyi yakınlarına tavsiye etmesine, tekrar ziyaret etme motivasyonunun güçlenmesine, işletmeye yönelik şikâyetlerinin azalmasına, dolayısıyla işletmenin pazarlama giderleri için daha az kaynak ayırmasına neden olmaktadır (Tuna 2006).

\section{Fonksiyonel Uyum}

Tüketiciler, gereksinimlerini tatmin edebilmek amacıyla, ürün veya markalardan çeşitli fonksiyonel özelliklere (temizlik, güvenlik, hizmet kalitesi, performans, dengeli fiyat vb.) sahip olmasını beklemektedir (Sirgy ve Johar 1999). Bu beklentiler doğrultusunda ürünü veya markay1 deneyimleyen tüketiciler, sunulan fonksiyonel özelliklerin kendi beklentileriyle ne düzeyde örtüştüğünü değerlendirmektedir. Söz konusu değerlendirme fonksiyonel uyum olarak adlandırılmaktadır (Sirgy ve Johar 1999; Sreejesh vd. 2015). Bu kapsamda fonksiyonel uyum, tüketicilerin ürünün performansıyla ilgili özelliklerine yönelik inançları ile karşılaştıkları özellikler arasındaki uyum olarak tanımlamakta ve tüketicinin satın alacağ ürünün özelliklerine yönelik algısı ile satın alma gerçekleştikten sonraki değerlendirmesi arasındaki farkı yorumlamak üzere kullanılmaktadır (Sreejesh vd. 2015).

Fonksiyonel uyumun yukarıdaki tanımlarında bahsi geçen beklenen fonksiyonel özellikler, ürün kategorisine göre farklılık göstermektedir. Örneğin; motor gücü, güvenlik, yakıt tüketimi, görünüş ve kalite bir otomobilin fonksiyonel özellikleri iken (Kressmann vd. 2006); ödediğinin karşılığını alma, ilgili personel, hizmet kalitesi, oda temizliği, otopark ve kasa hizmeti gibi hizmetler ise bir otelden beklenen fonksiyonel özelliklerdir (Lee 1992). Seyahat sürecinde turistlerin farklı beklen- 
tiler içerisinde olabileceğini ve bu beklentilerin karşılanması hususunda destinasyonun sergilediği performansı yorumlayacaklarını belirten Chon ve Olsen (1991), turistlerin bu değerlendirmelerinin destinasyona yönelik memnuniyet düzeyleri üzerinde etkili olduğunu savunmaktadır. Bu teorik çerçeveden hareketle yürütülen turizm araştırmaları, fonksiyonel uyumun müşteri memnuniyetini (Lee 1992; Ekinci vd. 2008; Sreejesh vd. 2015), marka tutumunu (Su 2015), davranışsal eğilimleri (Hung ve Petrick 2011) ve sadakati (Bosnjak vd. 2011; Sop 2017) olumlu etkilediğini göstermektedir.

\section{Benlik Uyumu}

Tüketici davranışını açıklamada sembolik tüketime dikkat çeken Levy (1959), ürünlerin fonksiyonel özelliklerinden ziyade sembolik anlamlarından dolayı satın alındığını ve tüketicilerin bu sembolik değerleri kendi benlikleriyle ilişkilendirdiğini ileri sürmüştür. Bu bağlamda, psikolojinin ve sosyal psikolojinin önemli bir araştırma konusu olan benlik kavramı, "bir kimsenin öz varliğ l, kişiliği, onu kendisi yapan şey, kendilik, şahsiyet" olarak tanımlanmaktadır (TDK 2005). Benlik uyumu ise tüketicinin kendisine ilişkin benlik algısı ile ürünün/markanın imajı arasındaki benzerliği veya uyumu ifade etmektedir (Sirgy ve Johar 1999).

Benlik uyumu kavramının kuramsal temeli, tüketicilerin satın aldıkları ürünleri kendi benliklerinin bir ifadesi olarak kullandıkları ve kendilerine yönelik benlik algıları ile benzer imaja sahip olduğunu düşündükleri ürünleri tercih ettikleri savıyla açıklanmaktadır (Sirgy 1985). Pazarlama alanında olduğu gibi turizm alanında da geçerliliği kabul edilen Benlik Uyumu Teorisi (Sirgy ve Su 2000; Litvin ve Goh 2002), ilk kez Chon ve Olsen (1991) tarafından turizm bağlamında tartışılmıştır. Buradan hareketle sürdürülen turizm araştırmalarında, benlik uyumunun müşteri memnuniyetini (Back 2005; Ekinci vd. 2008), marka tutumunu (Su 2015), davranışsal eğilimleri (Hung ve Petrick 2011; Usakli ve Baloglu 2011; Kılıç ve Sop 2012; Çabuk vd. 2013) ve sadakati (Bosnjak vd. 2011; Sop 2017) olumlu etkilediği ortaya konulmuştur.

\section{Müşteri Sadakati}

Müşteri sadakati, "başka ürün ya da hizmetin tercih edilmesine neden olabilecek durumlara ve pazarlama çabalarna rağmen, tercih edilen herhangi bir ürün ya da hizmetin gelecekte tekrar satın alınmastna veya kullanilmasina, dolayisiyla aynı marka ya da marka topluluğundan tekrarlı satın alınmasına iliş̧kin derinden bağlılık" şeklinde tanımlanmaktadır (Oliver 1999). Geleneksel sadakat yaklaşımına göre müşteri sadakati olgusu davranışsal, tutumsal ve bileşik sadakat bileşenlerinden oluşmaktadır (Bowen ve Chen 2001; Back ve Parks 2003). $\mathrm{Bu}$ kapsamda müşteri sadakatinin sadece tekrarlanan satın alma davranışıyla ilişkilendirilmesi davranışsal sadakati, duygular ve psikolojik bağlılık üzerinden yorumlanması tutumsal sadakati, hem davranışsal hem de tutumsal sadakatin gerçekleşmesi ise bileşik sadakati göstermektedir (Bowen ve Chen 2001). Oliver (1999) ise müşteri sadakatini bilişsel sadakat (markanın alternatiflerinden daha iyi olduğu inanc1), duygusal sadakat (markayı beğenme ve bağlllık hissetme), eğilimsel sadakat (markayı tekrar satın alma niyeti) ve eylemsel sadakat (markanın tekrarlı satın alınması) olmak üzere birbirini izleyen dört aşamalı bir süreç olarak yorumlamaktadır.

Pazarlama disiplininde yapılan çalışmalar, mevcut müşterilerin elde tutulması yoluyla yaratılan müşteri sadakatinin yoğun rekabet ortamındaki işletmeler için hayati önem taşıdığını göstermektedir (Tepeci 1999; Wilkins vd. 2010). Zira müşteri sadakati, bir markaya yönelik olumlu tutum ve zaman içerisindeki tekrarlı satın alma davranışlarının bir bileşimidir (Oliver 1999) ve işletmenin kârlılı̆̆ı ile yakından ilişkilidir (Bowen ve Chen 2001). Otel işletmelerinde müşteri sadakatini etkileyen faktörleri yorumlayan Tepeci (1999), özellikle müşteri memnuniyetine dikkat çekmektedir. Bu kapsamda müşteri memnuniyeti, bir ürünün satın alınması sonucunda oluşan olumlu tepkidir ve sadakatin önemli bir öncülü olarak kabul edilmektedir (Oliver 1999; Wilkins vd. 2010).

\section{Ilgili Araştırmalar ve Kuramsal Model}

Turizm sektörü üzerine yapılan araştırmalarda kalite, imaj ve algilanan değer müşteri memnu- 
niyetinin öncülleri olarak kabul görmektedir (Ladeira vd. 2016). Bazı araştırmacılar ise fonksiyonel uyum ve benlik uyumunu müşteri memnuniyetini olumlu etkileyen değişkenler arasında yorumlamaktadır (Chon ve Olsen 1991; Lee 1992; Ekinci vd. 2008; Sreejesh vd. 2015). Örneğin Sreejesh vd. (2015), otel müşterilerinin fonksiyonel beklentilerinin ne düzeyde karşılandığına dair çıkarımları ile otele yönelik memnuniyet düzeyleri arasında anlamlı bir ilişki olduğu sonucuna ulaşmıştır. Back (2005) ise müşterilerin benlik algılarıyla otel işletmesinin marka imajının örtüşmesi durumunda müşteri memnuniyetinin olumlu etkilendiğini ileri sürmüştür. Bu araştırmalardan hareketle mevcut araştırmanın ilk hipotezleri şu şekilde kurulmuştur:

$H_{1}$ : Müşterinin fonksiyonel beklentileri ile otel işletmesinin performansı arasındaki uyum müşteri memnuniyetini olumlu etkiler. Başka bir ifadeyle, fonksiyonel uyum müşteri memnuniyetinin bir öncülüdür.

$\mathrm{H}_{2}$ : Müşterinin benlik algısı ile otel işletmesinin imajı arasındaki uyum müşteri memnuniyetini olumlu etkiler. Başka bir ifadeyle, benlik uyumu müşteri memnuniyetinin bir öncülüdür.

Müşteri memnuniyetinin öncülleri olarak yorumlanabilen fonksiyonel uyum ve benlik uyu$\mathrm{mu}$, imaj uyumu teorisinin iki bileşenidir. Bu bileşenlerden benlik uyumunun fonksiyonel uyumu olumlu etkilediği iddia edilmektedir (Sirgy ve Su 2000). Sınırlı sayıdaki turizm araştırması da bu savı desteklemektedir (Hung ve Petrick 2011; Sreejesh vd. 2015). Örneğin, Sirgy ve Su (2000) ve Sirgy'e (2014) göre, kendi benlik algılaryyla destinasyonun imajı arasinda uyum olduğunu düşünen turistler destinasyona yönelik ilk izlenimlerini geliştirmiş olmaktadır. Bu olumlu ilk izlenim ise destinasyonun beklentileri karş1layabilecek bir destinasyon olduğu düşüncesini destekleyerek turistlerin fonksiyonel uyum alg1sinı etkileyebilmektedir (Sirgy ve Su 2000; Sirgy 2014). Belirtilen kuramsal altyapıdan hareketle müşteri memnuniyetinin öncülü olan iki değişken arasındaki ilişkiyi test etmek için aşağıdaki hipotez kurulmuştur:
H3: Müşterinin benlik algisı ile otel işletmesinin imajı arasındaki uyum, müşterinin beklenti-performans değerlendirmesini olumlu etkiler. Başka bir ifadeyle, benlik uyumu fonksiyonel uyum üzerinde anlamli bir etkiye sahiptir.

Turizm sektörü üzerine yapılan araştırmalarda; güven, ağızdan ağıza duyurum, satın alma niyeti ve sadakat müşteri memnuniyetinin ardılları olarak yorumlanmaktadır (Ladeira vd. 2016). Bu kapsamda, müşteri memnuniyetinin en önemli çıktısının ise sadakat olduğu düşünülmektedir (Oliver 1999; Tepeci 1999; Wilkins vd. 2010). Mevcut araştırmada da müşteri memnuniyetinin tutumsal sadakat üzerindeki etkisinin belirlenmesi amaçlanmış ve Oliver (1999) tarafından önerilen tutumsal sadakat bileşenleri müşteri memnuniyetinin ardılları olarak kabul edilmiştir. Yuksel vd. (2010) tarafından destinasyon, Back ve Parks (2003) ile Back (2005) tarafından ise otel bağlamında uygulanan bu yaklaşıma göre Oliver'ın (1999) çok boyutlu sadakat modeli (bilişsel sadakat duygusal sadakati, duygusal sadakat ise eğilimsel sadakati etkiler) turizm bağlamında da geçerlidir. Ancak, Yuksel vd. (2010) müşteri memnuniyetinin bilişsel sadakat üzerin-

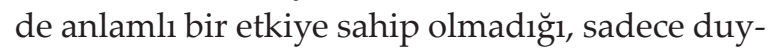
gusal ve eğilimsel sadakati olumlu etkilediği sonucuna ulaşmıştır. Back ve Parks (2003) ile Back (2005) ise müşteri memnuniyeti ile bilişsel sadakat arasında olumlu bir ilişki tespit etmiştir. Bu kuramsal çerçeveye dayanılarak müşteri memnuniyetinin ardıllarını tartışmak üzere aşağıdaki hipotezler geliştirilmiştir.

$H_{4}$ : Müşterinin otel işletmesinden memnun kalması, bu otel işletmesinin alternatiflerinden daha iyi olduğuna yönelik inancın olumlu etkiler. Başka bir ifadeyle, bilişsel sadakat müşteri memnuniyetinin bir ardilıdir.

$H_{5}$ : Müşterinin otel işletmesinden memnun kalmasl, bu otel işletmesine yönelik duygusal bağlilığını olumlu etkiler. Başka bir ifadeyle, duygusal sadakat müşteri memnuniyetinin bir ardılıdır.

$H_{6}$ : Müşterinin otel işletmesinden memnun kalmasl, bu otel işletmesini tekrar tercih etme eğilimini olumlu etkiler. Başka bir ifadeyle, eğilimsel sadakat müşteri memnuniyetinin bir ardılıdır. 
H7: Müşterinin otel işletmesinin alternatiflerinden daha iyi olduğuna yönelik inancl, otel işletmesine yönelik duygusal bağglılığını güçlendirir. Başka bir ifadeyle, bilişsel sadakat duygusal sadakat üzerinde anlaml bir etkiye sahiptir.

$H_{8}$ : Müş̧erinin otel işletmesine yönelik duygusal bağlilığı, bu otel işletmesini tekrar tercih etme eğilimini güçlendirir. Başka bir ifadeyle, duygusal sadakat eğilimsel sadakat üzerinde anlamlı bir etkiye sahiptir.

\section{YÖNTEM}

Birden çok değişken arasındaki etkileşimlerin belirlenmesi amaçlandığından, mevcut araştırma ilişkisel tarama modelinin uygulandığ 1 nicel bir araştırmadır. Araştırmada kullanılan veri toplama aracı çeşitli ölçeklerin bir araya getirilmesiyle oluşturulmuştur. Bunlar; Su (2015) tarafından geliştirilen otel işletmelerine yönelik fonksiyonel uyum ölçeği, Su vd. (2015) tarafından otel işletmelerine uyarlanan benlik uyumu ölçeği, Ekinci vd.'nin (2008) otel işletmelerine uyarladığı müşteri memnuniyeti ölçeği ve Back (2005) tarafından geliştirilen otel işletmelerine yönelik bilişsel, duygusal ve eğilimsel sadakat ölçekleridir. Ölçeklerin Türkçeye uyarlanması aşamasında altı uzmandan destek alınmış, ardından 35 katılımcıla bir pilot uygulama gerçekleştirilmiştir. Pilot uygulamanın sonucunda ölçek maddelerinin açıkça anlaşıldığ nıtlanabildiği belirlenmiştir.

Araştırmanın evreni, 2018 yılı yüksek turizm sezonunda Fethiye'deki beş yıldızlı otel işletmelerinde tatil yapan yerli turistlerdir. Evrenin tüm

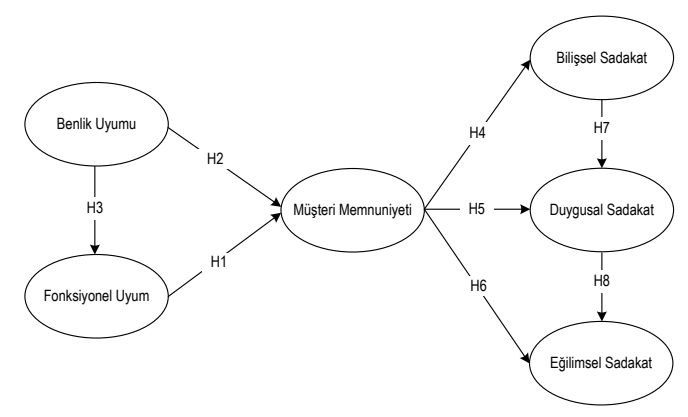

Şekil 1. Araştırmanın Kuramsal Modeli bireylerinden veri toplanması zaman ve maliyet açısından mümkün olmadığından ve evrenin kaç kişiden oluştuğu belirlenemediğinden mevcut araştırmada kolayda örnekleme tekniği uygulanmıştır. Veri toplama aşaması, uygulama izni alınabilen dört otel işletmesinde yürütülmüş ve araştırmaya 342 yerli turist gönüllü olarak katılmıştır. Verilerin SPSS yazılımına aktarılması sürecinde 33 veri toplama aracinın eksik doldurulduğu gözlenmiş ve geçerli olan 309 veri toplama aracı değerlendirmeye alınmıştır.

Araştırmada öncelikle Kolmogorov-Smirnov (K-S) testi ve ölçek maddelerinin basıklık ve çarpıklık değerleri üzerinden verilerin dağılımı incelenmiştir. K-S testinden ulaşılan $p$ değerlerinin 0,05 düzeyinden düşük olması ve çoğu maddenin basıklık ve çarpıklık katsayılarının \pm 1 aralığında yer almaması nedeniyle verilerin normal dağılmadığı kabul edilmiştir (Lei ve Lomax 2005). Verilerin normal dağılmadığ 1 durumlarda yapısal eşitlik modellemesi için en küçük kareler (partial least squares - PLS) yönteminin kullanılması önerilmektedir (Ali vd. 2018; Yeşiltaş vd. 2018). Dolayısıyla, araştırmanın kuramsal modelini analiz etmek için kovaryans temelli yapısal eşitlik modellemesi yerine varsyans temelli kısmi en küçük kareler yapısal eşitlik modellemesi (PLS-SEM) yöntemi uygulanmıştır. Bu aşamada, alanyazında yaygın biçimde kullanıldığı gözlemlenen SmartPLS (sürüm 3.2.7) yazılımından yararlanılmıştır.

\section{ANALIZ VE BULGULAR}

Araştırmada öncelikle katılımcıların özelliklerini belirlemeye yönelik tanımlayıcı analizler yapılmıştır. Tablo 1'de görüldüğü üzere, katılımcıların çoğunluğu erkek (yüzde 55) ve evli (yüzde 72,5) bireylerdir. Katılımcıların yaş ortalaması 39, ortalama aylık gelirleri ise 9700 TL'dir. Ancak, katılımcıların yaklaşık yüzde $26^{\prime}$ sı aylık gelirlerini belirtmek istememiştir. Araştırmaya katılan bireylerin oteldeki ortalama tatil süresi alt1-yedi gündür ve yaklaşık yüzde 50'si daha önceden aynı otelde en az bir kez tatil yapmıştır.

Araştırmanın kuramsal modelini analiz etmek için Anderson ve Gerbing (1988) tarafından önerilen iki aşamalı yaklaşım [ölçüm modelinin anali- 
Tablo 1. Katılımcıların Özellikleri

\begin{tabular}{|c|c|c|c|c|c|c|c|}
\hline & $n$ & $\%$ & Asgari & Azami & Ortalama & Mod & Medyan \\
\hline Cinsiyet & 307 & 99,4 & & & & & \\
\hline Kadın & 136 & 44,0 & & & & & \\
\hline Erkek & 171 & 55,3 & & & & & \\
\hline Belirtilmemiş & 2 & 0,6 & & & & & \\
\hline Yaş & 256 & 82,8 & 18 & 84 & 39,3 & 40 & 38,5 \\
\hline Belirtilmemiş & 53 & 17,2 & & & & & \\
\hline Medeni durum & 304 & 98,4 & & & & & \\
\hline Evli & 224 & 72,5 & & & & & \\
\hline Bekâr & 80 & 25,9 & & & & & \\
\hline Belirtilmemiş & 5 & 1,6 & & & & & \\
\hline Ortalama aylık gelir (TL) & 229 & 74,1 & 0 & 80000 & 9700 & 5000 & 5000 \\
\hline Belirtilmemiş & 80 & 25,9 & & & & & \\
\hline Oteldeki tatil süresi (gün) & 306 & 99 & 1 & 27 & 6,4 & 7 & 6 \\
\hline Belirtilmemiş & 3 & 1 & & & & & \\
\hline Geçmişte aynı otelde tatil yapma durumu & 308 & 99,7 & & & & & \\
\hline Evet & 153 & 49,5 & & & & & \\
\hline Hayır & 155 & 50,2 & & & & & \\
\hline Belirtilmemiş & 1 & 0,3 & & & & & \\
\hline
\end{tabular}

$z i$, ardından yapısal modelin analizi] uygulanmıştır. $\mathrm{Bu}$ bağlamda yapısal modelin test edilmesinden önce modelde yer alan örtük değişkenlerin yapı güvenirliğini ve geçerliğini test etmek için doğrulayıcı faktör analizi yapılmış ve ölçüm modeli yorumlanmıştır.

Tablo 2'de araştırmanın tüm değişkenlerine ilişkin faktör yükleri, Cronbach Alfa katsayıları (CA), yapı güvenirliği katsayıları (CR) ve çıkarılan ortalama varyans değerleri (AVE) görülmektedir. Ölçüm modelinde yer alan tüm örtük değişkenlerin maddelerine ilişkin faktör yüklerinin 0,70'ten yüksek olması, değişkenlerin CA ve CR değerlerinin 0,70'i aşması, AVE değerlerinin ise 0,50'ten büyük olması ölçüm modelindeki yapılar için yakınsama geçerliğinin sağlandığını göstermektedir (Ali vd. 2018). Yapılar arasındaki ayrışma geçerliği ise Fornell-Larcker Ölçütü (FLÖ) uygulanarak incelenmiştir (Hair vd. 2014; Ali vd. 2018). FLÖ'ye göre her yapının AVE değerinin karekökü, diğer yapılar ile bu yapı arasındaki korelasyon katsayılarından yüksek olmalıdır (Hair vd. 2014). Tablo 3'te yıldız (*) simgesiyle verilmiş olan $\sqrt{\mathrm{AVE}}$ değerlerinin diğer yapılar ile ilgili yapı arasındaki korelasyon değerlerinden yüksek olduğu görülmektedir. Bu durumda, mevcut araştırmanın ölçüm modelindeki tüm yapılar arasında ayrışma geçerliğinin sağlandığı söylenebilmektedir (Hair vd. 2014; Ali vd. 2018).

Araştırmada güvenirlik ve geçerlik ölçütlerinin sağlanmasının ardından veri setinde ortak yöntem varyansı (OYV) [comon method variance] sorununun olup olmadığı modeldeki yapılar için VIF değerlerinin hesaplanması yoluyla test edilmiş (Hair vd. 2014; Kock 2015) ve yapılar aras1 VIF değerlerinin 2,0 ile 3,3 arasında değiştiği gözlenmiştir. Kock'a (2015) göre VIF değerinin 3,3'ü, Hair vd.'ne (2014) göre ise beşi aşmaması gerekmektedir. Mevcut araştırmadaki VIF değerleri kabul edilebilir düzeyde olduğundan, araştırmanın veri setinde OYV sorununun olmadığ1 kabul edilmiştir.

Araştırmada yapısal modelin ve hipotezlerin test edilebilmesi için yol analizi yapılmıştır. Yol 
Tablo 2. Ölçüm Modeli

\begin{tabular}{|c|c|c|c|c|}
\hline Örtük Değişkenler ve Maddeler & Faktör Yükü & $C A$ & $C R$ & AVE \\
\hline Benlik Uyumu [1: Kesinlikle katılmıyorum - 5: Kesinlikle katılıyorum] & & 0,956 & 0,966 & 0,852 \\
\hline X Otel bir insan olsaydı, onunla aynı kişilik özelliklerine sahip olurduk. & 0,925 & & & \\
\hline X Otel benim nasıl birisi olduğumu yansıtmaktadır. & 0,943 & & & \\
\hline X Otel'in imajı benim kimliğimle uyumludur. & 0,935 & & & \\
\hline X Otel'i tercih eden kişiler benimle benzer özelliklere sahiptir. & 0,884 & & & \\
\hline X Otel'de kalmak benim kim olduğumu yansıtmaktadır. & 0,926 & & & \\
\hline Fonksiyonel Uyum [1: Kesinlikle katılmıyorum - 5: Kesinlikle katılıyorum] & & 0,943 & 0,959 & 0,854 \\
\hline X Otel, bir otelde olmasını istediğim her şeye sahiptir. & 0,933 & & & \\
\hline X Otel, en çok önemsediğim konularda iyi bir performans göstermektedir. & 0,929 & & & \\
\hline X Otel, otelde kaldığım süre içerisindeki tüm intiyaçlarımı karşılamaktadır. & 0,925 & & & \\
\hline X Otel, ödediğim ücretin karşılığını vermektedir. & 0,909 & & & \\
\hline Müşteri Memnuniyeti [1: Çok kötü - 5: Çok güzel] [1: Hiç değilim - 5: Çok m & um] & 0,968 & 0,984 & 0,969 \\
\hline X Otel'deki tatil deneyiminizi puanlayınız. & 0,984 & & & \\
\hline X Otel'den ne kadar memnun kaldığınızı puanlayınız. & 0,985 & & & \\
\hline Bilişsel Sadakat [1: Kesinlikle katılmıyorum - 5: Kesinlikle katılıyorum] & & 0,931 & 0,956 & 0,879 \\
\hline X Otel diğer otellerden daha kaliteli bir hizmet sunmaktadır. & 0,949 & & & \\
\hline X Otel'den daha iyi hizmet veren başka bir otel yoktur. & 0,927 & & & \\
\hline X Otel'in aynı kategorideki diğer otellerden daha fazla avantajı vardır. & 0,936 & & & \\
\hline Duygusal Sadakat [1: Kesinlikle katılmıyorum - 5: Kesinlikle katılıyorum] & & 0,948 & 0,966 & 0,906 \\
\hline X Otel'de kalmaktan keyif alıyorum. & 0,945 & & & \\
\hline X Otel'de kalırken kendimi daha iyi hissediyorum. & 0,960 & & & \\
\hline X Otel'i diğer otellerden daha çok beğeniyorum. & 0,950 & & & \\
\hline Eğilimsel Sadakat [1: Kesinlikle katılmıyorum - 5: Kesinlikle katılıyorum] & & 0,914 & 0,946 & 0,854 \\
\hline Diğer oteller daha düşük bir fiyat verse bile yine $X$ Otel'i tercih ederim. & 0,912 & & & \\
\hline Gelecekte tekrar X Otel'de kalırım. & 0,925 & & & \\
\hline Fethiye'de kalacaksam, ilk tercihim olarak X Otel'i düşünürüm. & 0,935 & & & \\
\hline
\end{tabular}

katsayılarının istatistiksel anlamlılı̆̆ını belirlemek üzere 5000 yeniden örnekleme yoluyla önyükleme (bootstrapping) tekniği uygulanmıştır. Yapisal modelin SRMR değeri 0,03 ve NFI değeri 0,90 olarak hesaplandığından, modelin yol analizi için uygun olduğu kabul edilmiştir (Merli vd. 2018). Ayrıca, modeldeki dışsal örtük değişkenlerin $Q^{2}$ (kestirimsel bağıntılılık-predictive relevance) değerleri, bu değişkenler reflektif ölçeklerle ölçüldüğü için blindfolding tekniği kullanılarak hesaplanmıştır (Hair vd. 2014; Ali vd. 2018). Bu bağlamda, tüm dışsal örtük değişkenlerin (içsel örtük değişken olan benlik uyumu dışındakiler) $\mathrm{Q}^{2}$ değerlerinin 0,436-0,749 arasında değiştiği ve $\mathrm{Q}^{2}>0$ olduğundan modelin kestirimsel bağıntıl1- lığının sağlandığı belirlenmiştir (Hair vd. 2014; Ali vd. 2018; Yeşiltaş vd. 2018). Diğer taraftan, modeldeki içsel değişkenlerin dışsal değişkenleri açıklama düzeylerini belirlemek üzere $\mathrm{R}^{2}$ değerleri incelenmiştir. Hair vd.'ne (2014) göre $0,50<R^{2}<0,75$ ise içsel değişkenin dışsal değişkeni açıklama oranı orta düzeyde yeterlidir. Şekil 2'de görüldüğü üzere her dişsal değişkenin içsel değişkenleri tarafından açıklanma oranı 0,50 'den yüksektir. $Q^{2}$ ve $R^{2}$ değerlerinin kabul edilebilir düzeyde bulunması nedeniyle, yapısal modelin uyum iyiliğinin sağlandığ 1 söylenebilmektedir (Ali vd. 2018).

Şekil 2'de sunulan yapısal modelin yol analizine ilişkin bulgulara göre; benlik uyumunun 
Tablo 3. Fornell-Larcker Ölçütü

\begin{tabular}{lcccccc}
\hline & BU & FU & MM & BS & DS & ES \\
\hline Benlik uyumu (BU) & $0,923^{*}$ & & & & & \\
\hline Fonksiyonel uyum (FU) & 0,837 & $0,924^{*}$ & & & & \\
\hline Müşteri Memnuniyeti (MM) & 0,734 & 0,811 & $0,984^{*}$ & & & \\
\hline Bilişsel sadakat (BS) & 0,874 & 0,820 & 0,713 & $0,938^{*}$ & & \\
\hline Duygusal sadakat (DS) & 0,857 & 0,843 & 0,814 & 0,878 & $0,952^{*}$ & $0,924^{*}$ \\
\hline Eğilimsel sadakat (ES) & 0,864 & 0,849 & 0,775 & 0,890 & 0,906 & \\
\hline
\end{tabular}

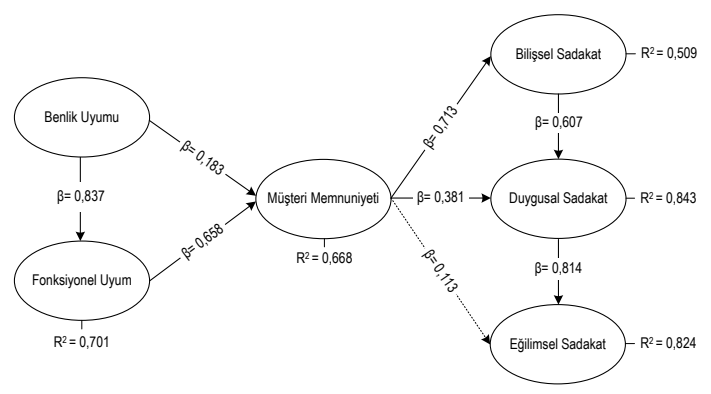

Şekil 2. Yapısal Modelin Yol Analizi

fonksiyonel uyum $(\beta=0,837 ; \mathrm{t}=37,408 ; \mathrm{p}<0,05)$ ve müşteri memnuniyeti $(\beta=0,183 ; t=2,424 ; p<0,05)$ üzerinde, fonksiyonel uyumun ise müşteri memnuniyeti üzerinde olumlu etkisi bulunmaktadır $(\beta=0,658 ; t=9,355 ; p<0,05)$. Bu bağlamda, araştırmanın $\mathrm{H}_{1}, \mathrm{H}_{2}$ ve $\mathrm{H}_{3}$ hipotezleri desteklenmiştir. Diğer taraftan, müşteri memnuniyetinin bilişsel sadakati $(\beta=0,713 ; t=24,599 ; p<0,05)$ ve duygusal sadakati $(\beta=0,381 ; t=9,935 ; p<0,05)$ olumlu etkilediği, ancak eğilimsel sadakat üzerinde anlamlı bir etki sergilemediği tespit edilmiştir $(\beta=0,113$; $\mathrm{t}=1,940 ; \mathrm{p}>0,05)$. Dolayısıyla $\mathrm{H}_{4}$ ve $\mathrm{H}_{5}$ desteklenmiş, $\mathrm{H}_{6}$ ise desteklenmemiştir. Son olarak, bilişsel sadakatin duygusal sadakati $(\beta=0,607 ; \mathrm{t}=16,847$; $\mathrm{p}<0,05)$, duygusal sadakatin ise eğilimsel sadakati olumlu etkilediği belirlenmiş $(\beta=0,814$; $\mathrm{t}=14,364 ; \mathrm{p}<0,05)$, bu doğrultuda $\mathrm{H}_{7}$ ve $\mathrm{H}_{8}$ desteklenmiştir.

\section{SONUÇ VE DEĞERLENDIRME}

Bu araştırmada, fonksiyonel uyumun ve benlik uyumunun otel işletmelerine yönelik müşteri memnuniyetini etkilediği belirlenmiştir. Dolayısıyla, otel müşterilerinin fonksiyonel beklentile- rinin (oteldeyken tüm gereksinimlerin karşılanması, en çok önemsenen konularda iyi bir performans sunulması, bir otelde olması istenilen her şeyin sağlanması ve ödenen ücretin karşılığının sunulması) karşılandığına dair çıkarımları [fonksiyonel uyum] ve otelin kendi benlik algilarıyla uyumlu olduğunu düşünmeleri (ziyaretçi özellikleri ve otel imajının kendilerini yansıtması) [benlik uyumu] müşteri memnuniyetini arttırmaktadır. Araştırmanın bu sonucu; Chon ve Olsen (1991), Lee (1992), Back (2005), Ekinci vd. (2008) ve Sreejesh vd. (2015) tarafından yürütülen turizm araştırmalarının sonuçlarıyla örtüşmektedir. İlgili araştırmalar fonksiyonel uyumun benlik uyumundan etkilendiğini de göstermektedir (Hung ve Petrick 2011; Sreejesh vd. 2015). Bu araştırmada da müşteri memnuniyetinin öncüllerinden benlik uyumunun fonksiyonel uyumu etkilediği tespit edilmiştir. Dolayısıyla, otel müşterilerinin fonksiyonel uyum değerlendirmesi yaparken benlik uyumunu dikkate aldıkları söylenebilmektedir. Sirgy'nin (2014) ileri sürdüğü teorik yaklaşımdan hareketle bu durum şu şekilde yorumlanabilir: "Kendi benlik algılarıyla otelin imajı arasında bir uyum olduğunu düşünen turistler otele yönelik ilk izlenimlerini geliştirmiş olmaktadır. Bu olumlu ilk izlenim ise otelin beklentileri karşılayabilecek bir otel olduğu düşüncesini destekleyerek turistlerin fonksiyonel uyum algısını olumlu etkilemektedir". Bu bağlamda, mevcut araştırmada fonksiyonel uyumun müşteri memnuniyeti üzerinde benlik uyumundan daha etkili olduğu belirlenmiştir. Bu bul$\mathrm{gu}$, turistlerin destinasyon memnuniyeti (Chon ve Olsen 1991) ve kruvaziyer tatili memnuniyeti (Hung ve Petrick 2011) üzerine yapılan önceki araştırmaların sonuçlarını desteklemektedir. Ancak ilgili alanyazın incelendiğinde, müşteri 
memnuniyeti üzerine kurulan araştırma modellerinde imaj uyumu teorisinin göz ardı edildiği görülmektedir. Alanyazındaki bu boşluğun doldurulması için fonksiyonel uyum, benlik uyumu ve müşteri memnuniyeti arasındaki ilişkilerin gelecek araştırmalarda da tartışılması önerilmektedir.

Müşteri memnuniyetinin ardılları üzerindeki doğrusal etkileri ve bu değişkenler arasındaki ilişkiler incelendiğinde, öncelikle müşteri memnuniyetinin bilişsel ve duygusal sadakati doğrudan etkilediği ancak eğilimsel sadakat üzerinde anlamlı bir etki sergilemediği tespit edilmiştir. Diğer bir ifadeyle, otel işletmesinden duyulan memnuniyet düzeyi arttıkça, otel işletmesinin alternatiflerinden daha iyi olduğu yönündeki inanç da güçlenmektedir [bilişsel sadakat]. Artan müşteri memnuniyeti otel işletmesinin daha çok beğenilmesine ve ona karşı duygusal bir bağlılı̆̆ın geliştirilmesine neden olurken [duygusal sadakat], işletmenin gelecekte tercih edilmesinde [eğilimsel sadakat] ise tek başına yeterli olmamaktadır. Fakat müşteri memnuniyetinden etkilenen duygusal sadakat, eğilimsel sadakati desteklemektedir. Bu durumda Oliver (1999) tarafından önerilen ve Yuksel vd. (2010) tarafından destinasyon, Back ve Parks (2003) ve Back (2005) tarafından ise otel işletmesi bağlamında doğrulanan sadakat modelinin [bilişsel sadakat duygusal sadakati, duygusal sadakat ise eğilimsel sadakati olumlu etkiler] bu araştırmada da desteklendiği söylenebilmektedir. Diğer taraftan, Yuksel vd. (2010) memnuniyetin destinasyona yönelik bilişsel sadakat üzerinde anlamlı bir etkisi olmadığı$\mathrm{n} 1$, sadece duygusal ve eğilimsel sadakati olumlu etkilediğini belirtmektedir. Back ve Parks (2003) ile Back (2005) ise müşteri memnuniyeti ile otel işletmelerine yönelik bilişsel sadakat arasında anlamlı bir ilişki bulsa da memnuniyetin duygusal ve eğilimsel sadakat üzerindeki etkilerini incelememiştir. Dolayısıyla mevcut araştırmada ulaşılan müşteri memnuniyeti ve sadakat bileşenleri arasındaki ilişkilerin ortaya çıkarılması alanyazına önemli bir katkı sağlamaktadır. Ancak otel işletmeleri bağlamında memnuniyet ve sadakat bileşenleri arasındaki ilişkilerin henüz yeterince incelenmediği görüldüğünden, bu iliş- kilerin gelecek araştırmalarda da sorgulanması önerilmektedir.

Araştırmada ulaşılan sonuçlar doğrultusunda uygulamaya dönük bazı çıkarımlar yapılabilir. Müşteri memnuniyetinin arttırılmasında fonksiyonel uyumun benlik uyumundan daha etkili olması, otel müşterilerinin sembolik değerlendirmeden çok beklenti-performans kıyaslaması yaptıklarını göstermektedir. Dolayısıyla, otel işletmelerinde imaj geliştirme çalışmaları yapılırken otelin sembolik imajından önce fonksiyonel imajının vurgulanması önerilmektedir. Diğer taraftan, müşteri memnuniyeti doğrudan eğilimsel sadakati etkilemese de sadakatin temel aşamaları olan bilişsel ve duygusal sadakati desteklemektedir. Bu nedenle, uygulamada sıkça karşılaşılan "memnun müssteri oteli tekrar ziyaret eder" şeklindeki düşüncenin "memnun müşteri öncelikle otelin rakiplerden üstün oldŭ̆una inanır ve otele karşı bir duygusal bağ geliştirirse bu oteli tekrar ziyaret eder" olarak yorumlanması gerekmektedir.

Mevcut araştırmanın bazı sınırlılıkları bulunmaktadır. Bunlardan ilki, benlik uyumunun gerçek benlik uyumu boyutuyla sınırlandırılmış olmasıdır. Bu nedenle gelecek araştırmalarda benlik uyumunun ideal, sosyal ve ideal sosyal boyutlarının (bkz. Sirgy ve Su 2000) müşteri memnuniyetine etkisi incelenebilir. Ayrıca, araştırmada müşteri sadakati sadece tutumsal sadakatin bileşenleriyle sınırlandırılmış, aktif davranışı içeren eylemsel/davranışsal sadakat (bkz. Oliver 1999) kapsam dişında tutulmuştur. Bunun temel nedeni, eylemsel sadakatin ölçümü için sadece tekrarlı müşteriden/misafirden (repeat guest) veri toplama zorunluluğudur. Diğer taraftan Back (2005) otel işletmelerinde sadakatin davranış boyutundan çok tutumsal boyutunun önemine dikkat çekmektedir. Ancak, gelecek araştırmalarda amaçlı örnekleme yoluyla (ya da müşteri listesine ulaşılarak olasılıklı bir örnekleme tekniğinin uygulanmasıyla) belirlenen tekrarlı misafirlerden veri toplanarak bu araştırmada test edilen yapısal model genişletilebilir.

\section{TESSEKKÜR}

Öneri ve destekleriyle araştırmanın veri analizi sürecine katkı sağlayan Doç. Dr. Murat YEŞILTASŞ́a teşekkürlerimi sunarım. 


\section{KAYNAKÇA}

Ali, F., Kim, W. G., Li, J. ve Cobanoglu, C. (2018). A Comparative Study of Covariance and Partial Least Squares Based Structural Equation Modelling in Hospitality and Tourism Research, International Journal of Contemporary Hospitality Management, 30(1): 416-435.

Anderson, J. C. ve Gerbing, D. W. (1988). Structural Equation Modeling in Practice: A Review and Recommended Two-Step Approach, Psychological Bulletin, 103(3): 411423.

Back, K. J. (2005). The Effects of Image Congruence on Customers' Brand Loyalty in the Upper Middle-Class Hotel Industry, Journal of Hospitality \& Tourism Research, 29(4): 448-467.

Back, K. J. ve Parks, S. C. (2003). A Brand Loyalty Model Involving Cognitive, Affective, and Conative Brand Loyalty and Customer Satisfaction, Journal of Hospitality $\mathcal{E}$ Tourism Research, 27(4): 419-435.

Bosnjak, M., Sirgy, M. J., Hellriegel, S. ve Maurer, O. (2011). Postvisit Destination Loyalty Judgments Developing and Testing a Comprehensive Congruity Model, Journal of Travel Research, 50(5): 496-508.

Bowen, J. T. ve Chen, S. L. (2001). The Relationship between Customer Loyalty and Customer Satisfaction, International Journal of Contemporary Hospitality Management, 13(5): 213-217.

Çabuk, S., Nakıboğlu, B. ve Canoğlu, M. (2013). Algılanan Otel İmajı ve Hizmet Kalitesi ile Tekrar Satın Alma Niyeti Arasındaki İlişkiler, Anatolia: Turizm Araştırmaları Dergisi, 24(1): 96-108.

Chi, C. G. Q. ve Qu, H. (2008). Examining the Structural Relationships of Destination Image, Tourist Satisfaction and Destination Loyalty: An Integrated Approach, Tourism Management, 29(4): 624-636.

Chon, K. S. ve Olsen, M. D. (1991). Functional and Symbolic Congruity Approaches to Consumer Satisfaction/Dissatisfaction in Tourism, Journal of the International Academy of Hospitality Research, 3: 2-22.

Ekinci, Y., Dawes, P. L. ve Massey, G. R. (2008). An Extended Model of the Antecedents and Consequences of Consumer Satisfaction for Hospitality Services, European Journal of Marketing, 42(1/2): 35-68.

Hair Jr, J. F., Hult, G. T. M., Ringle, C. M. ve Sarstedt, M. (2014). A Primer on Partial Least Squares Structural Equation Modeling (PLS-SEM). Kaliforniya: Sage Publications, Inc.

Hung, K. ve Petrick, J. F. (2011). The Role of Self-and Functional Congruity in Cruising Intentions, Journal of Travel Research, 50(1): 100-112.

Kılıç, B. ve Sop, S. A. (2012). Destination Personality, SelfCongruity and Loyalty, Journal of Hospitality Management and Tourism, 3(5): 95-105.

Kılıç, İ. ve Pelit, E. (2004). Yerli Turistlerin Memnuniyet Düzeyleri Üzerine bir Araştırma, Anatolia: Turizm Araştırmaları Dergisi, 15(2): 113-124.

Kock, N. (2015). Common Method Bias in PLS-SEM: A Full Collinearity Assessment Approach, International Journal of e-Collaboration (IJeC), 11(4): 1-10.
Kressmann, F., Sirgy, M. J., Herrmann, A., Huber, F., Huber, S. ve Lee, D. J. (2006). Direct and Indirect Effects of SelfImage Congruence on Brand Loyalty, Journal of Business Research, 59(9): 955-964.

Ladeira, W. J., Santini, F. D. O., Araujo, C. F. ve Sampaio, C. H. (2016). A Meta-Analysis of the Antecedents and Consequences of Satisfaction in Tourism and Hospitality, Journal of Hospitality Marketing \& Management, 25(8): 975-1009.

Lee, C. L. (1992). A Study of Japanese Guests' Satisfaction with Hotel Attributes and Performance in Taiwan. (Basılmamış Yüksek Lisans Tezi). Las Vegas: Nevada Üniversitesi, Otel İşletmeciliği Ana Bilim Dalı.

Lei, M. ve Lomax, R. G. (2005). The Effect of Varying Degrees of Nonnormality in Structural Equation Modeling, Structural Equation Modeling, 12(1): 1-27.

Levy, S. J. (1959). Symbols for Sale, Harvard Business Review, 37(4): 117-124.

Litvin, S. W. ve Goh, H. K. (2002). Self-Image Congruity: A valid Tourism Theory?, Tourism Management, 23(1): 8183.

Merli, R., Preziosi, M., Acampora, A., Lucchetti, M. C. ve Ali, F. (2018). The Impact of Green Practices in Coastal Tourism: An Empirical Investigation on An EcoLabelled Beach Club, International Journal of Hospitality Management, (Basımda), https://doi.org/10.1016/j. ijhm.2018.08.011.

Oliver, R. L. (1999). Whence Consumer Loyalty?, The Journal of Marketing, 63 (Special Issue): 33-44.

Sirgy M. J. ve Johar, J. S. (1999). Toward an Integrated Model of Self-Congruity and Functional Congruity, E-European Advances in Consumer Research, 4: 252-256.

Sirgy, M. J. (2014). Revisiting Self-Congruity Theory in Travel and Tourism. İçinde N. K. Prebensen, J. S. Chen ve M. Uysal (Editörler), Creating Experience Value in Tourism (ss. 63-78). Londra: CAB Internationals.

Sirgy, M. J. (1985). Using Self-Congruity and Ideal Congruity to Predict Purchase Motivation, Journal of Business Research, 13(3): 195-206.

Sirgy, M. J. ve Su, C. (2000). Destination Image, SelfCongruity, and Travel Behavior: Toward an Integrative Model, Journal of Travel Research, 38(4): 340-352.

Sop, S. A. (2017). Marka Kişiliği, Benlik Uyumu ve Fonksiyonel Uyumun Marka Sadakatine Etkileri: Otel İşletmelerine Yönelik Bir Araştırma. (Basılmamış Doktora Tezi). Eskişehir: Anadolu Üniversitesi, Turizm İşletmeciliği Ana Bilim Dalı.

Sreejesh, S., Mitra, A. ve Sahoo, D. (2015). The Impact of Customer's Perceived Service Innovativeness on Image Congruence, Satisfaction and Behavioral Outcomes, Journal of Hospitality and Tourism Technology, 6(3): 288310.

Su, A. Y. L. (2004). Customer Satisfaction Measurement Practice in Taiwan Hotels, International Journal of Hospitality Management, 23(4): 397-408.

$\mathrm{Su}, \mathrm{N}$. (2015). US-Based Hotel Brand Personality. (Basılmamış Doktora Tezi). Washington: Washington Devlet Üniversitesi, Otel İşletmeciliği Anabilim Dalı. 
Su, N., Mariadoss, B. J. ve Reynolds, D. (2015). Friendship on Social Networking Sites: Improving Relationships between Hotel Brands and Consumers, International Journal of Hospitality Management, 51(8): 76-86.

Tepeci, M. (1999). Increasing Brand Loyalty in the Hospitality Industry, International Journal of Contemporary Hospitality Management, 11(5): 223-230.

Tuna, M. (2006). Cultural Approximation and Tourist Satisfaction. İçinde M. Kozak ve L. Andreu (Editörler), Progress in Tourism Marketing (ss. 207-219). Amsterdam: Elsevier.

Türk Dil Kurumu [TDK]. (2005). Türkçe Sözlük. Ankara: 4. Akşam Sanat Okulu Matbaası.
Usakli, A. ve Baloglu, S. (2011). Brand Personality of Tourist Destinations: An Application of Self-Congruity Theory, Tourism Management, 32(1): 114-127.

Wilkins, H., Merrilees, B. ve Herington, C. (2010). The Determinants of Loyalty in Hotels, Journal of Hospitality Marketing \& Management, 19(1): 1-21.

Yeşiltaş, M., Kanten, P. ve Kanten, S. (2018). Yetenek Yönetimi Stratejilerinin İşe Gömülmüşlük Üzerindeki Etkisinde Psikolojik Sözleşme Algısının Aracılık Rolü, 6. Örgütsel Davranış Kongresi (ss. 1063-1078). Türkiye: Isparta.

Yuksel, A., Yuksel, F. ve Bilim, Y. (2010). Destination Attachment: Effects on Customer Satisfaction and Cognitive, Affective and Conative Loyalty, Tourism Management, 31(2): 274-284.

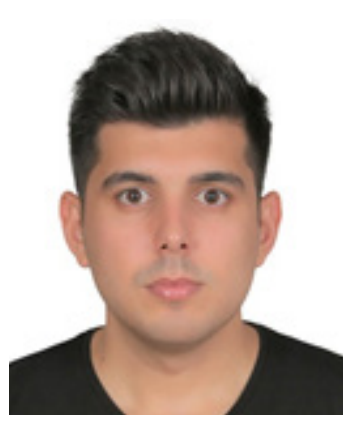

Serhat Adem SOP

Muğla Sıtkı Koçman Üniversitesi Turizm İșletmeciliği ve Otelcilik Yüksekokulu Konaklama İşletmeciliği Bölümü'nden mezun oldu (2010). Yüksek lisans derecesini aynı üniversitede Turizm İşletmeciliği Dalı'ndan (2013), doktora derecesini ise Anadolu Üniversitesi'nde Turizm İşletmeciliği Dalı'ndan aldı (2017). Lisansüstü öğrenim süreci boyunca Muğla Sıtkı Koçman Üniversitesi, Anadolu Üniversitesi ve Burdur Mehmet Akif Ersoy Üniversitesi'nde Arş. Gör. olarak çalıştı (2011-2018). Halen Burdur Mehmet Akif Ersoy Üniversitesi Turizm İşletmeciliği ve Otelcilik Yüksekokulu'nda Dr. Öğr. Üyesi olarak görev yapmaktadır. Temel çalışma alanları; turizm pazarlaması, turizmde markalaşma ve tüketici davranışlarıdır. 